the fact that it applies step for step when $d$ is replaced by $\Delta$, the finite difference symbol, giving the result $\triangle \log z=m \frac{\Delta z}{z}$, with $m$ independent of $z$, which is absurd.

I am not opposed to the method of infinitesimals when properly presented. It is logically only an abbreviation of the method of limits, and I should, for my own satisfaction, always want to test new results obtained by it, with the method of limits in full. I should be glad to see Professor Bowser revise his book. There are some good things in it. I trust Professor Bowser and the other authors mentioned will take my criticisms in the spirit they are intended. We are all liable to make mistakes, and if I should indulge in book-writing to any extent, there would no doubt be some sins of that kind of my own commission, especially in the subject of infinitesimals.

Rese Polytechnic Institute, Terre Haute, Ind., March 16, 1893.

\section{Color of Flowers}

WILL some of the readers of Science tell me what to use for preserving the color of flowers when pressing them?

Saint Joseph, Mich.

JEANNE NEAL.

\section{BOOK-REVIEWS.}

Extinct Monsters. By Rev. H. N. Hutchinson, B.A., F.G.S. New York, D. Appleton \& Co.

THIs book is, as the author states, a popular account of some of the larger forms of ancient animal life. It is impossible to say too much in favor of the proper kind of popular science. The only argument that scientific research can advance for itself, is that the results of its work will appeal to mankind in general. Scientific investigators must therefore encourage in every possible way all attempts to render science popular and cherish every successful writer in this line. To write popular scientific works is an extremely difficult matter, and there are few in the world who are capable of it. The scientist who is best familiar with the facts is usually either unable to put his facts in a form to be enjoyed by the general reader, or is afraid of losing easte among his friends by doing so. But there is no scientist who does not hail any popular exposition of scientific truth.

There are two faults into which a writer of popular science is liable to fall. If he is too much of a scientist he becomes too technical, and if he is not enough of a scientist he becomes too discursive and too much inclined to fill his pages with rhetorical flourishes. The present book does not fully avoid either of these two faults. At times the reader is led along through a series of rhetorical exclamation points and feels that the author is endeavoring to amuse rather than instruct; and at other times be finds technical terms used which he certainly cannot understand in their proper significance. The book aims to reach those unacquainted with geology, but assumes a knowledge of the succession of geological ages and considerable familiarity with the different strata of rocks. Probably the book would be more instructive if the author had treated his subjects in a little more systematic way, and had not been quite so desirous of introducing popular names on one page to please his non-scientific readers and scientific names on the next page to satisfy his sense of scientific consistency.

But, in spite of the trifling inperfections, it must be stated that this book is an emphatic success as a bit of popular writing. The style is easy and interesting. When one takes up the book, he is inclined to read page after page and chapter after chapter without any desire to lay the book down. The author has skilfully interspersed striking incidents connected with the discovery of special fossil types in such a way as to add vivacity and life to the whole.

The most valuable and interesting part of the whole to all must be the figures in which the book abounds, drawn by J. Smit. These figures are partly skeletons, and represent our present actual knowledge of the hard parts of the extinct monsters as collected in the museums of the world. But the figures which will most appeal to the reader are the restorations of these ancient monsters in the flesh. Of course, restorations of extinct monsters have been made many times, and they have been constantly changed as new facts are discovered. The author would not pretend that his restorations are final, but it can be claimed fairly, and will be easily admitted, that the restorations, as given in the figures of the present book, are the best that have been made up to the present time, and are certainly nearer the truth in each case than those which have preceded them.

One is very naturally inclined to feel, after a cursory reading of this book, that the ancient world was filled with nothing but monsters, and perhaps the author would have given a better picture of ancient life if he had interspersed with his monsters some of the smaller but no less interesting types of animals. But, on the whole, the book is a success as a bit of popular writing, and can be recommended to all.

Advanced Lessons in Human Physiology. By Oliver P. Jenkins, Ph.D. 60 cents.

Primary Lessons in Human Physiology. By the same author. 30 cents. Indianapolis, Indiana School Book Co.

THESE two little books are published in the Indiana State series of school text-books, and are designed, one for primary schools and the other for advanced schools. One is glad to see a departure from the plan of teaching simple anatomy and the introduction of a physiological basis of treatment. The physiology of man is studied from the standpoint of general biological truth, and the student may here actually learn something of the law's of life.

Interpretation of Nature. By Professor Nathaniel S. SHaler. Boston, Houghton, Mifflin \& Co. \$1.25.

IT is not very common that a person of as much scientific repute as Professor Shaler of Harvard ventures even indirectly to discuss in print the question of the relations of science to theological problems, and for this reason there is especial interest in the pages of this little book. Professor Shaler, in his preface, tells us that his first contact with natural science had the effect of leading him far away from Christianity, but that of late years further insight into the truths of nature have forced him back again towards the grounds from which he had departed. The body of this publication is a discussion of various problems of natural science for the purpose of pointing out how it is that the discoveries of science fail to be in themselves a satisfactory answer to man's questions as to the philosophy of nature. The different chapters of the book are not and do not pretend to be arguments upon the subject of the relation of theology and science. They are rather thoughts upon certain phases of scientific truth and a general inference as to lack of satisfaction which the mind can find if it rests in scientific truths alone. He discusses the general appreciation of nature historically, and then more in detail the general subject of biological evolution, especially in its philosophical aspect. The general conclusion of the whole is as to the lack of a satisfactory foundation for thought in science itself, and the unavoidable feeling which must come to a thoughtful student of some power unknown and lying deeper than the phenomenon which science studies on the surface. Even in regard to the scientific aspect of the doctrine of Christianity, Professor Shaler tells us that "the doctrine of Christ is the summit and crown of the organic series." One cannot but be forcibly reminded of Spencer's grand generalization that scientific fact and religious thought are both truths, and that the final outcome of study is to be a fundamental union of the two.

This book of Professor Shaler's will be especially interesting to two classes of readers. First to those who have passed through somewhat of this same mental history as that which Professor Shaler points out as his own. This will include a body of scientists who had learned to look deeper than the phenomena and to wonder concerning the underlying truths, a class of thinkers which seems to be a growing one at the present time. A second class is the great body of readers who are and always have been in thorough sympathy with religious teachings, and will rejoice to see a scientist of such high standing taking a position so in harmony with the most advanced religious truth. While, on the 